\title{
Pengaruh Game-Based Learning Terhadap Motivasi dan Prestasi Belajar
}

\author{
Komang Redy Winatha, I Made Dedy Setiawan \\ redywin@stiki-indonesia.ac.id, dedy.setiawan@stiki-indonesia.ac.id \\ Program Studi Teknik Informatika, STMIK STIKOM Indonesia
}

The Effect Of Game-Based Learning Towards The Learning Motivation And Achievement

\begin{abstract}
The curriculum requirement requires the lecturer to be creative in developing the learning style. However, in interpersonal skill subject, the lecturer only provides things that available on the textbook conventionally and focusing on the material accomplishment of the curriculum without considering the learning expected output. To resolve that problem, the lecturer needs to modify the learning style by providing a learning innovation. One of the alternatives is implementing game-based learning model by playing media card. Therefore, the research objective was to describe positive effect of game-based learning model towards collegian's learning motivation and achievement in Interpersonal Skill subject in STMIK STIKOM Indonesia. The research method used was Quasi-Experiment with non-equivalent control group design. The research instrument used was a motivation questionnaire and learning achievement test. The research result showed that there was a positive effect of gamebased learning model towards Collegian's motivation and learning achievement in Interpersonal Skill subject.
\end{abstract}

Keywords: Games, Fun, Learning, Innovative, Soft Skills

Received date: 18 Desember 2019

Revised date: 25 Juni 2020

Accepted date: 24 September 2020

\section{PENDAHULUAN}

Sistem pendidikan Indonesia menghadapi tantangan yang sangat besar dalam mempersiapkan sumber daya manusia yang berkualitas dan mampu bersaing dalam Masyarakat Ekonomi ASEAN (MEA). Fenomena ini menyebabkan persaingan di bursa tenaga kerja akan semakin meningkat. MEA akan menjadi panggung yang sangat tepat untuk menunjukkan dan membuktikan kualitas dan kuantitas tidak hanya produk, tetapi juga sumber daya manusia Indonesia kepada negara-negara lain secara terbuka. Upaya tepat untuk menyiapkan sumber daya manusia yang berkualitas dan bermutu tinggi adalah pendidikan.

Berdasarkan Undang-Undang Nomor 20 Tahun 2003 tentang sistem pendidikan nasional, pendidikan berfungsi untuk mengembangkan kemampuan dan membentuk watak serta peradaban bangsa yang bermartabat dalam rangka mencerdaskan kehidupan bangsa. Berdasarkan undang-undang tersebut, pendidikan bertujuan untuk mengembangkan potensi mahasiswa agar menjadi manusia yang beriman dan bertaqwa kepada Tuhan Yang Maha Esa, berakhlak mulia, sehat, berilmu, cakap kreatif, mandiri dan menjadi warga negara yang demokratis serta bertanggung jawab. Tujuan pendidikan nasional Indonesia merupakan implementasi dari empat pilar pendidikan yang dicanangkan oleh UNESCO yaitu: (1) learning how to know, (2) learning how to do, (3) learning how to be, dan (4) learning how to live together (Harjali, 2011). Mengacu pada empat pilar tersebut, pendidikan seharusnya mampu mengarahkan peserta didik tidak hanya pada penguasaan keilmuan (knowing) dan implementasinya (doing). Melainkan juga mampu membentuk manusia yang percaya diri akan kemampuannya (being) serta mampu beradaptasi dan bertoleransi di manapun mereka berada (living together) dengan penuh toleransi, simpati, empati, etika dan unsur psikologis lainnya (softskill).

Salah satu dilema yang dihadapi Indonesia dalam bidang pendidikan khususnya pendidikan di perguruan tinggi adalah penekanan pada keterampilan teknis (hard skill) saja sedangkan aspek soft skill kurang diperhatikan. Pengamatan terhadap praktek pendidikan menunjukkan bahwa, proses penyampaian semata-mata hanya terfokus pada ketuntasan mata kuliah. Bagaimana keterkaitan materi dan bagaimana materi tersebut dapat digunakan untuk memecahkan masalah dalam kehidupan sehari- 
hari, kurang mendapat perhatian. Pendidikan soft skill tentu menjadi kebutuhan yang sangat penting dalam dunia pendidikan guna membekali mahasiswa sebelum masuk ke dunia kerja. Terdapat sembilan belas soft skill yang dibutuhkan perusahaan dari lulusan perguruan tinggi sebagai calon karyawan (Manara, 2014). Sebelas soft skill yang paling dibutuhkan adalah kemampuan komunikasi, kemampuan interpersonal, kemampuan bekerja secara tim maupun secara individu, kemampuan bekerja di bawah tekanan, kepribadian yang baik, jujur, motivasi kerja, disiplin, kepemimpinan, ulet, dan teliti serta detail. Perlunya kemampuan soft skill bagi lulusan perguruan tinggi, juga didukung oleh hasil survei yang dilakukan National Association of Colleges and Employers (NACE) tahun 2002. Menurut survei tersebut, indikator terpenting dari kesuksesan seseorang adalah kemampuan komunikasi, integritas, kerja sama, interpersonal, dan etika (Rantelino, 2015). Untuk itu, STMIK STIKOM Indonesia sebagai salah satu perguruan tinggi di Bali menghadirkan mata kuliah interpersonal skill. Interpersonal skills merupakan salah satu indikator dari soft skill (Wahyuni, 2011), yaitu suatu keterampilan untuk memahami dan berkomunikasi dengan orang lain serta memahami suasana hati, tempramen, dan motivasi guna membentuk dan menjaga hubungan antar manusia (Chan, 2000).

Dalam prakteknya, terdapat beberapa permasalahan yang dialami oleh dosen dalam pembelajaran interpersonal skill, diantaranya: (a) tingkat keabstrakkan materi yang tinggi, mengakibatkan rendahnya motivasi belajar mahasiswa dan seringkali menjadi alasan yang kurang memuaskan dalam pencapaian prestasi belajar mahasiswa; (b) kurangnya sumber belajar terkait materi interpersonal skill; dan (c) tuntutan kurikulum mengharuskan dosen agar lebih kreatif dalam mengembangkan model pembelajaran. Akan tetapi dalam pembelajaran, suasana kelas cenderung membosankan karena sebagian besar dosen hanya menyajikan apa yang ada di buku secara konvensional, dan hanya fokus terhadap ketuntasan materi yang ada pada kurikulum tanpa memperhatikan hasil belajar yang diharapkan.

Mengacu pada hal tersebut, perlu adanya suatu pendekatan pembelajaran inovatif yang mampu mengakomodasi kegiatan belajar menjadi lebih menyenangkan. Pendekatan pembelajaran inovatif tersebut adalah pembelajaran berbasis permainan (game-based learning). Game-based learning merupakan sebuah sistem yang diterapkan dalam proses pendidikan, dimana pengguna (dosen) dapat mengadopsi sebuah permainan untuk kebutuhan minat kognitif dan motivasi belajar (Vusić, Bernik, \& Geček, 2018). Connoly berpendapat (Stiller \& Schworm, 2019), game-based learning berarti menggunakan permainan dalam konteks pendidikan untuk mencapai tujuan pendidikan. Menurut McGonical (Hidayat, 2018) games mengandung empat fitur utama dalam aspek pendidikan, antara lain: (1) tujuan atau hasil yang akan diperoleh oleh peserta dari aktivitasnya di dalam game; (2) Aturan, merupakan batasan-batasan mengenai bagaimana caranya pemain dapat mencapai tujuannya di dalam game; (3) feedback system, menunjukkan kepada peserta seberapa dekat mereka dengan tujuan yang ingin diraih di dalam permainan; dan (4) voluntary participation, setiap orang terlibat di dalam sebuah game atas dasar pemahaman bahwa mereka secara suka rela menerima adanya goals, rules, dan feedback system yang sudah ditetapkan.

Empat fitur tersebut merupakan alasan utama yang mendasari pemilihan strategi game-based learning dalam pembelajaran, selain kemampuan permainan dalam meningkatkan motivasi (Anjani, Fatchan, \& Amirudin, 2016), minat belajar (Aini, 2018), efektivitas belajar (Liu \& Chen, 2013) dan hasil belajar (Noviyanti, 2018). Penelitian terbaru juga menyatakan bahwa, integrasi permainan dalam pembelajaran dapat menarik minat peserta didik dalam memahami materi (Luhsasi \& Permatasari, 2020) dan efektif digunakan sebagai media latihan mandiri (Sidarta \& Yunianta, 2019). Permainan yang digunakan dalam penelitian ini adalah kartu siki. Siki merupakan hasil pengembangan media pembelajaran mata kuliah interpersonal skill yang dikemas dalam bentuk permainan kartu. Permainan ini memodifikasi tampilan dan aturan permainan Uno, serta mengaitkannya cerita-cerita rakyat nusantara Indonesia dengan materi mata kuliah interpersonal skill. 


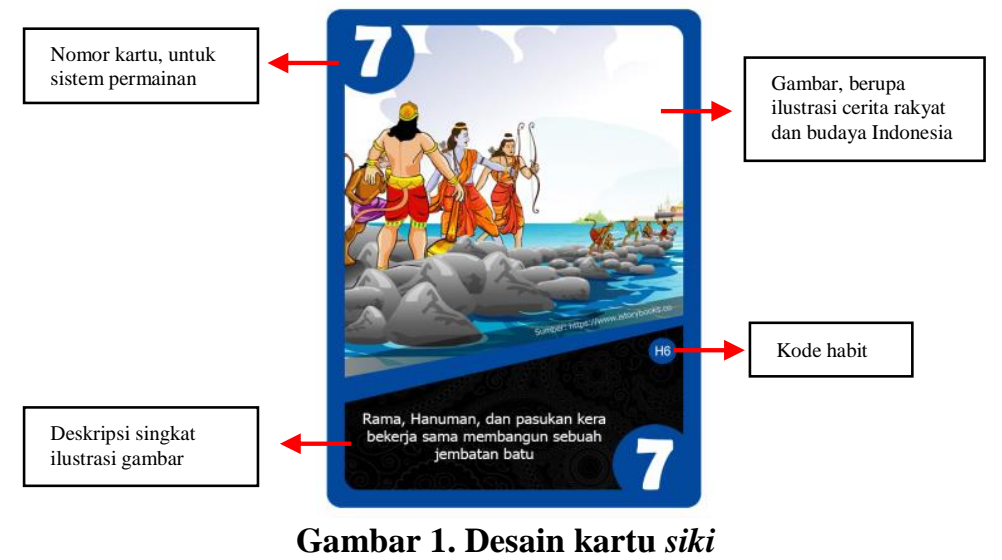

Beberapa penelitian telah mengeksplorasi efektivitas game-based learning dalam pembelajaran. Diharapkan bahwa dalam pencapaian penelitian ini akan menunjukkan pengaruh positif game-based learning berbantuan permainan kartu siki terhadap motivasi dan hasil belajar.

\section{KAJIAN PUSTAKA}

\section{a) Game-Based Learning}

Menurut Torrente, game-based learning adalah penggunaan game dengan tujuan yang serius (yaitu tujuan pendidikan), sebagai alat yang mendukung proses pembelajaran secara siginifikan (Pratiwi $\&$ Musfiroh, 2014). Ada beberapa manfaat digunakannya permainan dalam pembelajaran, antara lain (De Freitas, 2006):

1. Memotivasi dan melibatkan seluruh peserta didik dalam pembelajaran.

2. Melatih kemampuan peserta didik seperti kemampuan literasi dan keterampilan berhitung.

3. Sebagai media terapi untuk mengatasi kesulitan kognitif.

4. Memainkan peran atau profesi tertentu sebelum praktek dalam kehidupan nyata.

5. Memberdayakan peserta didik sebagai produsen multimedia atau konten berbasis game.

Dalam beberapa tahun terakhir, banyak penelitian yang mengungkapkan bahwa game-based learning sangat efektif apabila benar-benar diterapkan dalam pembelajaran. Pembelajaran berbasis permainan memiliki peranan penting dalam mempengaruhi motivasi peserta didik, dan mampu membuat peserta didik merasa senang, lebih bersemangat, tertantang, dan menjalin kerjasama antar teman (Anjani et al., 2016). Penelitian lain juga menyebutkan, pembelajaran berbasis permainan khususnya permainan kartu dapat meningkatkan atensi, motivasi, dan rasa ingin tahu (Azizah Mashami, Andayani, \& Sofia, 2014).

\section{b) Motivasi Belajar}

Kata motivasi berasal dari bahasa Latin yaitu motivus, yang berarti bergerak atau menggerakkan. Motivasi juga dapat di definisikan sebagai usaha yang dapat menyebabkan seseorang atau kelompok orang tertentu tergerak melakukan sesuatu karena ingin mencapai tujuan yang dikehendakinya atau mendapat kepuasan dengan perbuatannya (Syarif, 2012). Motivasi memegang peranan yang cukup penting dalam pembelajaran karena dapat memberikan semangat dan rasa senang. Peserta didik yang termotivasi akan dengan mudah diarahkan, diberi penugasan, cenderung memiliki rasa ingin tahu yang besar, aktif dalam mencari informasi tentang materi yang dijelaskan oleh pendidik serta menggunakan proses kognitif yang lebih tinggi untuk mempelajari dan menyerap pelajaran yang diberikan (Slavin, 2009).

Menurut Sardiman, proses pembelajaran akan mencapai keberhasilan apabila peserta didik memiliki motivasi belajar yang baik (Emda, 2017). Sebagai seorang pendidik, guru maupun dosen harus memotivasi peserta didik untuk belajar demi tercapainya tujuan dan tingkah laku yang diinginkan. Berdasarkan uraian di atas, dapat disimpulkan bahwa peserta didik yang memiliki motivasi dalam belajar akan melakukan aktivitas belajar dengan baik sehingga tujuan pembelajaran yang sudah ditetapkan bisa dicapai.

\section{c) Prestasi Belajar}

Belajar dapat diartikan sebagai suatu proses perubahan perilaku tetap dari belum tahu menjadi tahu, dari tidak paham menjadi paham, dari kurang terampil menjadi lebih terampil, dan dari kebiasaan 
lama menjadi kebiasaan baru, serta bermanfaat bagi lingkungan maupun individu itu sendiri (AlTabany, 2015). Untuk mengetahui sejauh mana peserta didik telah melaksanakan proses belajarnya dengan baik, maka perlu dilakukan pengukuran terhadap kemampuan belajar peserta didik tersebut. Hasil pengukuran tersebut, itulah yang dinamakan sebagai prestasi belajar. Prestasi belajar didefinisikan sebagai tingkat kemanusiaan yang dimiliki peserta didik dalam menerima, menolak, dan menilai informasi-informasi yang diperoleh dalam pembelajaran (Hamdu, Ghullam; Agustina, 1989). Sejalan dengan definisi tersebut, peneliti lain juga mengemukakan prestasi belajar merupakan suatu pencapaian yang diperoleh peserta didik dalam kegiatan belajar (mengerjakan tugas, ulangan ataupun ujian) berbentuk nilai ataupun angka yang diperoleh dari evaluasi (Lomu \& Widodo, 2014). Belajar memperlihatkan sejauh mana konsep atau kompetensi yang menjadi tujuan pembelajaran (instructional objective) atau tujuan perilaku (behavioral objective) yang mampu dikuasai peserta didik pada akhir jangka waktu pengajaran (Slavin, 2009).

\section{METODE PENELITIAN}

Penelitian ini merupakan jenis penelitian kuantitatif dengan pendekatan quasieksperimental designs. Kelompok yang digunakan pada penelitian berjumlah 2 kelompok, yaitu kelompok kontrol yang menggunakan model pembelajaran langsung (direct learning) dan kelompok eksperimen yang menggunakan game-based learning. Tempat penelitian berlokasi di STMIK STIKOM Indonesia, Denpasar-Bali. Eksperimen ini dilakukan pada semester ganjil yang didesain selama 3 kali pertemuan (3 minggu). Populasi dalam penelitian ini adalah mahasiswa program studi sistem komputer yang sedang menempuh mata kuliah interpersonal skill. Seluruh mahasiswa tersebut pada prinsipnya memiliki kemampuan dasar yang relatif sama.

Penentuan kelas kontrol dan kelas eksperimen dilakukan dengan teknik pengundian dari beberapa kelas yang ada. Instrumen pengumpulan data adalah lembar kuesioner untuk motivasi mahasiswa dan lembar tes untuk prestasi belajar mahasiswa. Kedua instrument, diberikan sebelum dan sesudah perlakuan pada masing-masing kelompok sampel yang berlangsung sebanyak 3 kali pertemuan. Data yang diperoleh kemudian dianalisis dan diuji dengan statistik parametrik uji-f, uji-t dan uji univariat.

\section{HASIL PENELITIAN DAN PEMBAHASAN}

Berikut ini deskripsi data hasil penelitian untuk kelas kontrol dan kelas eksperimen:

Tabel 1. Deskripsi Data Penelitian Kelas Kontrol

\begin{tabular}{|c|c|c|c|c|c|}
\hline \multirow{2}{*}{$\mathrm{N}$} & \multirow{2}{*}{ Valid } & Motivasi Awal & Motivasi Akhir & Pretest & Posttest \\
\hline & & 31 & 31 & 31 & 31 \\
\hline Mean & & 49.33 & 51.88 & 55.67 & 63.92 \\
\hline Median & & 49.00 & 53.50 & 55.00 & 63.50 \\
\hline Mode & & 51 & 65 & 53 & 60 \\
\hline Std. Deviation & & 8.223 & 12.284 & 4.371 & 4.232 \\
\hline Variance & & 67.623 & 150.987 & 19.101 & 17.906 \\
\hline Minimum & & 34 & 22 & 45 & 57 \\
\hline Maximum & & 73 & 70 & 66 & 75 \\
\hline
\end{tabular}

Tabel 2. Deskripsi Data Penelitian Kelas Eksperimen

\begin{tabular}{|c|c|c|c|c|c|}
\hline \multirow{2}{*}{$\mathrm{N}$} & \multirow{2}{*}{ Valid } & Motivasi Awal & Motivasi Akhir & Pretest & Posttest \\
\hline & & 31 & 31 & 31 & 31 \\
\hline Mean & & 70.23 & 82.32 & 48.55 & 78.48 \\
\hline Median & & 71.00 & 84.00 & 49.00 & 78.00 \\
\hline Mode & & 71 & 72 & 51 & 77 \\
\hline Std. Deviation & & 4.766 & 6.944 & 3.223 & 3.275 \\
\hline Variance & & 22.714 & 48.226 & 10.389 & 10.725 \\
\hline Minimum & & 63 & 72 & 40 & 72 \\
\hline Maximum & & 80 & 98 & 54 & 89 \\
\hline
\end{tabular}


Pengaruh Game-Based Learning Terhadap Motivasi dan Prestasi Belajar

(Komang Redy Winatha, I Made Dedy Setiawan)

Berdasarkan hasil uji normalitas dan homogenitas (Tabel 3), maka seluruh kelompok data telah dinyatakan memenuhi syarat.

Tabel 3. Hasil Uji Prasyarat

\begin{tabular}{|c|c|c|}
\hline \multirow{2}{*}{ Data Skor } & \multicolumn{2}{|c|}{ Nilai P terhadap $\alpha$} \\
\hline & Uji Normalitas & Uji Hom \\
\hline \multicolumn{3}{|c|}{ Kelompok Kontrol } \\
\hline Motivasi Awal & $0.098>0.05 \rightarrow$ Normal & \multirow{2}{*}{$0.732>0.05 \rightarrow$ Homogen } \\
\hline Motivasi Akhir & $0.438>0.05 \rightarrow$ Normal & \\
\hline Pretest & $0.343>0.05 \rightarrow$ Normal & \multirow{2}{*}{$0.162>0.05 \rightarrow$ Homogen } \\
\hline Posttest & $0.502>0.05 \rightarrow$ Normal & \\
\hline \multicolumn{3}{|c|}{ Kelompok Eksperimen } \\
\hline Motivasi Awal & $0.360>0.05 \rightarrow$ Normal & \multirow{4}{*}{$\begin{array}{l}0.385>0.05 \rightarrow \text { Homogen } \\
0.412>0.05 \rightarrow \text { Homogen }\end{array}$} \\
\hline Motivasi Akhir & $0.158>0.05 \rightarrow$ Normal & \\
\hline Pretest & $0.126>0.05 \rightarrow$ Normal & \\
\hline Posttest & $0.068>0.05 \rightarrow$ Normal & \\
\hline
\end{tabular}

Tabel 4. Uji Anova Skor Motivasi

\begin{tabular}{cccccc}
\hline & Sum of Squares & Df & Mean Square & F & Sig. \\
\hline Between Groups & 1729.958 & 13 & 133.074 & 0.764 & 0.031 \\
\hline Within Groups & 1740.667 & 10 & 174.067 & & \\
\hline Total & 3470.625 & 23 & & & \\
\hline
\end{tabular}

Hasil analisis pada Tabel 4 membuktikan secara signifikan adanya perbedaan motivasi belajar mahasiswa antara pembelajaran dengan direct learning dibanding dengan game-based learning. Hal tersebut terlihat dari nilai sig. output $(\mathrm{P}) 0.031$ yang berada dibawah $0.05(\alpha)$.

Tabel 5. Output Paired Samples t-Test Motivasi Belajar Mahasiswa

\begin{tabular}{|c|c|c|c|c|c|c|c|}
\hline \multicolumn{5}{|c|}{ Paired Differences } & \multirow[t]{3}{*}{$\mathrm{t}$} & \multirow[t]{3}{*}{ df } & \multirow{3}{*}{$\begin{array}{l}\text { Sig. } \\
\text { (2 tailed) }\end{array}$} \\
\hline \multirow[t]{2}{*}{ Mean } & \multirow[t]{2}{*}{$\begin{array}{c}\text { Std. } \\
\text { Deviation }\end{array}$} & \multirow[t]{2}{*}{$\begin{array}{l}\text { Std. Error } \\
\text { Mean }\end{array}$} & \multicolumn{2}{|c|}{$\begin{array}{l}\text { 95\% Confidence of the } \\
\text { Difference }\end{array}$} & & & \\
\hline & & & Lower & Upper & & & \\
\hline-12.097 & 4.504 & 0.809 & -13.749 & -10.445 & -14.952 & 30 & 0.000 \\
\hline
\end{tabular}

Pada Tabel 5, terbukti secara signifikan adanya peningkatan motivasi belajar mahasiswa dalam mata kuliah interpersonal skill akibat penerapan model game-based learning. Hal tersebut terlihat dari nilai sig. output $(\mathrm{P}) 0.000$ yang berada dibawah $0.05(\alpha)$

Tabel 6. Rerata Skor Motivasi Belajar Mahasiswa

\begin{tabular}{cccccc}
\hline \multicolumn{3}{c}{ Model } & Direct Learning & \multicolumn{3}{c}{ Model Game-Based Learning } \\
\hline Awal (A) & Akhir (B) & B - A & Awal (A) & Akhir (B) & B - A \\
\hline 49.33 & 51.88 & 0.55 & 70.23 & 82.32 & 12.09 \\
\hline \multicolumn{2}{l}{ Peningkatan motivasi } & 0.55 point & \multicolumn{4}{c}{ Peningkatan motivasi 12.09 point } \\
\hline
\end{tabular}

Berdasarkan Tabel 6 dapat dilihat bahwa rerata skor motivasi belajar mahasiswa kelas kontrol meningkat 0.55 point $(0.55 \%)$. Sementara itu rerata skor motivasi belajar mahasiswa kelas eksperimen yang meningkat 12.1 point (12.1\%). Jika dibandingkan peningkatan rerata skor motivasi belajar kedua kelompok maka peningkatan motivasi belajar mahasiswa kelas eksperimen lebih besar dibandingkan peningkatan skor motivasi belajar mahasiswa kelas kontrol.

Tabel 7. Uji Anova Skor Prestasi Belajar

\begin{tabular}{lccccc}
\hline & Sum of Squares & Df & Mean Square & F & Sig. \\
\hline Between Groups & 6494.208 & 11 & 590.383 & 2.868 & 0.042 \\
\hline Within Groups & 2470.417 & 12 & 205.868 & & \\
\hline Total & 8964.625 & 23 & & & \\
\hline
\end{tabular}


Hasil analisis pada Tabel 7 membuktikan secara signifikan adanya perbedaan prestasi belajar mahasiswa antara pembelajaran dengan direct learning dibanding pembelajaran game-based learning. Hal tersebut terlihat dari nilai sig. output (P) 0.042 yang berada dibawah $0.05(\alpha)$.

Tabel 8. Output Paired Samples t-Test Prestasi Belajar Mahasiswa

\begin{tabular}{|c|c|c|c|c|c|c|c|}
\hline \multicolumn{5}{|c|}{ Paired Differences } & \multirow[t]{3}{*}{$\mathrm{t}$} & \multirow[t]{3}{*}{ df } & \multirow{3}{*}{$\begin{array}{c}\text { Sig. } \\
(2 \text { tailed })\end{array}$} \\
\hline \multirow[t]{2}{*}{ Mean } & \multirow[t]{2}{*}{$\begin{array}{c}\text { Std. } \\
\text { Deviation }\end{array}$} & \multirow[t]{2}{*}{$\begin{array}{l}\text { Std. Error } \\
\text { Mean }\end{array}$} & \multicolumn{2}{|c|}{$\begin{array}{l}\text { 95\% Confidence of the } \\
\text { Difference }\end{array}$} & & & \\
\hline & & & Lower & Upper & & & \\
\hline-29.935 & 4.575 & 0.822 & -31.614 & -28.257 & -36.433 & 30 & 0.000 \\
\hline
\end{tabular}

Selain itu hasil analisis selanjutnya pada Tabel 8, membuktikan secara signifikan adanya peningkatan prestasi belajar mahasiswa dalam mata kuliah interpersonal skill akibat penerapan model game-based learning. Hal tersebut terlihat dari nilai sig. output (P) 0.000 yang berada dibawah 0.05 $(\alpha)$.

Tabel 9. Rerata Skor Prestasi Belajar Mahasiswa

\begin{tabular}{cccccc}
\hline & Model Direct Learning & \multicolumn{3}{c}{ Model Game-based Learning } \\
\hline Awal (A) & Akhir (B) & B - A & Awal (A) & Akhir (B) & B - A \\
\hline \multirow{2}{*}{55.67} & 63.92 & 8.25 & 48.55 & 78.48 & 29.93 \\
\cline { 2 - 5 } & Peningkatan prestasi 8.25 & \multicolumn{3}{c}{ Peningkatan prestasi 29.93 } \\
\hline
\end{tabular}

Pada Tabel 9 menunjukkan adanya peningkatan prestasi belajar mahasiswa di masing-masing kelompok. Peningkatan terbesar terjadi pada mahasiswa kelas eksperimen. Rerata skor prestasi belajar mahasiswa kelas kontrol meningkat signifikan 8.25 point. Sementara itu rerata skor prestasi belajar mahasiswa kelas eksperimen meningkat signifikan 29.93 point. Jika dibandingkan keduanya maka peningkatan skor prestasi belajar mahasiswa kelas eksperimen lebih besar dibanding peningkatan prestasi belajar mahasiswa kelas kontrol.

Tabel 10. Test of Between-Subjects Effects (Motivasi * Model Pembelajaran)

\begin{tabular}{lrrrrc}
\hline \multicolumn{1}{c}{ Source } & $\begin{array}{c}\text { Type III Sum } \\
\text { of Squares }\end{array}$ & df & \multicolumn{1}{c}{$\begin{array}{c}\text { Mean } \\
\text { Square }\end{array}$} & F & Sig. \\
\hline Corrected Model & $12540.528^{\mathrm{a}}$ & 1 & 12540.528 & 135.163 & 0.000 \\
\hline Intercept & 243612.528 & 1 & 243612.528 & $2.626 \mathrm{E} 3$ & 0.000 \\
\hline Model & $\mathbf{1 2 5 4 0 . 5 2 8}$ & $\mathbf{1}$ & $\mathbf{1 2 5 4 0 . 5 2 8}$ & $\mathbf{1 3 5 . 1 6 3}$ & $\mathbf{0 . 0 0 0}$ \\
\hline Error & 4917.399 & 53 & 92.781 & & \\
\hline Total & 279589.000 & 55 & & & \\
\hline Corrected Total & 17457.927 & 54 & & & \\
\hline
\end{tabular}

Analisis selanjutnya pada Tabel 10 ditemukan ada pengaruh interaksi antara model pembelajaran terhadap motivasi belajar mahasiswa. Hal tersebut terlihat dari nilai sig. output 0.000 yang berada dibawah $0.05(\alpha)$.

Tabel 11. Test of Between-Subjects Effects (Prestasi * Model Pembelajaran)

\begin{tabular}{lrrrrr}
\hline \multicolumn{1}{c}{ Source } & $\begin{array}{c}\text { Type III Sum } \\
\text { of Squares }\end{array}$ & df & $\begin{array}{c}\text { Mean } \\
\text { Square }\end{array}$ & F & \multicolumn{1}{c}{ Sig. } \\
\hline Corrected Model & $2870.534^{\mathrm{a}}$ & 1 & 2870.534 & 207.393 & 0.000 \\
\hline Intercept & 274304.861 & 1 & 274304.861 & $1.982 \mathrm{E} 4$ & 0.000 \\
\hline Model & $\mathbf{2 8 7 0 . 5 3 4}$ & $\mathbf{1}$ & $\mathbf{2 8 7 0 . 5 3 4}$ & $\mathbf{2 0 7 . 3 9 3}$ & $\mathbf{0 . 0 0 0}$ \\
\hline Error & 733.575 & 53 & 13.841 & & \\
\hline Total & 289733.000 & 55 & & & \\
\hline Corrected Total & 3604.109 & 54 & & & \\
\hline
\end{tabular}


Pengaruh Game-Based Learning Terhadap Motivasi dan Prestasi Belajar

(Komang Redy Winatha, I Made Dedy Setiawan)

Analisis juga memperlihatkan (berdasarkan Tabel 11) bahwa ada pengaruh interaksi antara model pembelajaran terhadap prestasi belajar mahasiswa. Hal tersebut terlihat dari nilai sig. output 0.000 yang berada dibawah $0.05(\alpha)$.

Pembelajaran dengan model game-based learning mampu mengubah paradigma pembelajaran yang semula teacher center menuju student center. Berdasarkan teori belajar konstruktivis dinyatakan bahwa belajar akan lebih bermakna ketika siswa terlibat dalam membangun pengetahuan mereka sendiri. Teori ini menekankan pada penyediaan kesempatan kepada siswa untuk membuat penilaian dan interpretasi dari situasi yang mereka alami sendiri (Hussain, 2012). Salah satu model pembelajaran inovatif yang melibatkan mahasiswa dalam kegiatan pemecahan masalah dan memberi peluang untuk bekerja secara otonom mengkonstruksikan cara belajar mereka sendiri adalah game-based learning. Model pembelajaran ini membantu mahasiswa membangun pembelajaran yang bermakna dan menstimulasi perkembangan mereka dengan memberikan pengalaman belajar yang menyenangkan. Pengalaman belajar yang menyenangkan ini, tentunya akan berdampak pada minat dan motivasi mahasiswa. Minat dan motivasi mahasiswa yang meningkat, akan memicu rasa ingin tahu dan kemudian mengarah pada eksplorasi lebih lanjut dan lebih mendalam dari apa yang telah mereka lakukan (Lu Chung Chin \& Effandi Zakaria, 2015). Penelitian sejenis juga berdapat hal yang sama, bahwa game-based learning dapat meningkatkan prestasi dan sikap belajar mahasiswa (Yien, Hung, Hwang, \& Lin, 2011). Oleh karena itu, integrasi permainan dalam proses pembelajaran menunjukkan hasil yang menguntungkan dimana mahasiswa menunjukkan perubahan positif dalam motivasi dan prestasi belajar. Mahasiswa akan belajar bagaimana bekerja sama, bergantian, berbagi materi, dan saling mengoreksi kesalahan mereka selama proses bermain. Dosen harus memainkan peranan penting sebagai fasilitator dan harus selalu memberikan bimbingan pada waktu dan situasi yang tepat. Sebab, penggunaan permainan dalam proses pembelajaran tidak berarti bahwa mahasiswa diperbolehkan bermain tanpa arah dan tanpa pengawasan. Bermain adalah hal yang cukup penting dalam dunia pendidikan karena mereka akan benar-benar belajar banyak melalui kegiatan bermain. Oleh karena itu, diharapkan bahwa hasil penelitian ini dapat berfungsi sebagai panduan bagi dosen dalam mengintegrasikan kegiatan bermain sebagai bagian dari proses pembelajaran.

\section{SIMPULAN DAN SARAN}

Berdasarkan hasil penelitian, dapat diambil kesimpulan sebagai berikut: (1) terdapat perbedaan motivasi belajar secara signifikan antara kelas yang menggunakan model direct learning dengan kelas yang menggunakan game-based learning model; (2) terdapat perbedaan prestasi belajar secara signifikan antara kelas yang menggunakan model direct learning dengan kelas yang menggunakan game-based learning model; (3) motivasi belajar mahasiswa meningkat secara signifikan karena penerapan model pembelajaran game-based learning; dan (4) prestasi belajar mahasiswa meningkat secara signifikan karena penerapan model pembelajaran game-based learning.

Peneliti memberikan saran untuk berbagai pihak yang berkepentingan terhadap penelitian ini, yaitu: (1) para dosen pengampu, khususnya dosen pengampu mata kuliah interpersonal skill dapat menerapkan game-based learning model ini karena terbukti berpengaruh positif terhadap prestasi dan motivasi belajar; dan (2) apabila diterapkan dalam pembelajaran, dosen harus dapat mengkondisikan kelas agar tidak terjadi kegaduhan.

\section{DAFTAR PUSTAKA}

Aini, F. N. (2018). Pengaruh Game Based Learning Terhadap Minat dan Hasil Belajar pada Mata Pelajaran Ekonomi Siswa Kelas XI IPS. JUPE, 6(3), 249-255.

Al-Tabany, T. I. B. (2015). Mendesain Model Pembelajaran Inovatif Progresif dan Kontekstual. Jakarta: Kencana.

Anjani, K. D., Fatchan, A., \& Amirudin, A. (2016). Pengaruh Pembelajaran Berbasis Turnamen dan Games Terhadap Motivasi Belajar Siswa. Jurnal Pendidikan: Teori, Penelitian, Dan Pengembangan, 1(9), 1787-1790.

Azizah Mashami, R., Andayani, Y., \& Sofia, B. F. D. (2014). Pengembangan Media Kartu Koloid untuk Meningkatkan Hasil Belajar Siswa, 13(4), 407-414. 
Chan, D. W. (2000). Learning and teaching through the multiple-intelligences perspective: Implications for curriculum reform in Hong Kong. Education Research Journal, 15(2), 187-201.

De Freitas, S. (2006). Learning in Immersive worlds A review of game-based learning Prepared for the JISC e-Learning Programme. JISC ELearning Innovation, 3.3(October 14), 73. https://doi.org/10.1111/j.1467-8535.2009.01024.x

Emda, A. (2017). Kedudukan Motivasi Belajar Siswa dalam Pembelajaran. Lantanida Journal, 5(2), 93-196.

Hamdu, Ghullam; Agustina, L. (1989). Pengaruh Motivasi Belajar Siswa Terhadap Pestasi Belajar IPA di Sekolah Dasar. Jurnal Penelitian Pendidikan, 12(1), 87-102.

Harjali. (2011). Urgensi Pendekatan Multikultur dalam Pendidikan. Cendekia, 9(2), 205-216.

Hidayat, R. (2018). Game-Based Learning : Academic Games sebagai Metode Penunjang Pembelajaran $\begin{array}{llll}\text { Kewirausahaan. Buletin } & \text { Psikologi, } & \text { 71-85. }\end{array}$ https://doi.org/10.22146/buletinpsikologi.30988

Hussain, I. (2012). Use of Constructivist Approach in Higher Education: An Instructors' Observation. Creative Education, 03(2), 179-184. https://doi.org/10.4236/ce.2012.32028

Liu, E. Z. F., \& Chen, P.-K. (2013). The Effect of Game-Based Learning on Students' Learning Performance in Science Learning - A Case of "Conveyance Go." Procedia - Social and Behavioral Sciences, 103(2013), 1044 - 1051. https://doi.org/10.1016/j.sbspro.2013.10.430

Lomu, L., \& Widodo, sri adi. (2014). Pengaruh Motivasi Belajar dan Disiplin Belajar terhadap Prestasi Belajar Matematika Siswa. Prosiding Seminar Nasional Etnomatnesia, 745-751.

Lu Chung Chin \& Effandi Zakaria. (2015). Effect of Game-Based Learning Activities on Children 's Positive Learning and Prosocial Behaviours (Kesan Aktiviti Pembelajaran Berasaskan Permainan terhadap Pembelajaran Positif dan Tingkah Laku Prososial Kank-Kanak). Jurnal Pendidikan Malaysia, 40(2), 159-165. https://doi.org/10.17576/jpen-2015-4002-08

Luhsasi, D. I., \& Permatasari, C. L. (2020). Trade Game Akuntasi Untuk Siswa Sekolah Menengah Atas. Scholaria: Jurnal Pendidikan Dan Kebudayaan, 10(1), 51-59.

Manara, M. U. (2014). Hard Skills dan Soft Skills pada Bagian Sumber Daya Manusia di Organisasi Industri. Jurnal Psikologi Tabularasa, 9(1), 37-47.

Noviyanti, G. V. (2018). Pengaruh Game Based Learning terhadap Hasil Belajar Mata Pelajaran Ekonomi Kelas X SMA, 6(2), 110-115.

Pratiwi, A. S., \& Musfiroh, T. (2014). Pengembangan Media Game Digital Edukatif untuk Pembelajaran Menulis Laporan Perjalanan Siswa Sekolah Menengah Pertama. LingTera, 1(2), 123-135.

Rantelino, H. (2015). Hasil Survei Nace USA Mengenai Kualitas Lulusan Perguruan Tinggi. Retrieved from https://www.kompasiana.com/heriyanto_rantelino/550e6098813311c02cbc6483/hasilsurvei-nace-usa-mengenai-kualitas-lulusan-perguruan-tinggi

Sidarta, K. T., \& Yunianta, T. N. H. (2019). Pengembangan Kartu Domano ( Domino Matematika Trigono ) Sebagai Media Pembelajaran Pada Matakuliah Trigonometri. Scholaria: Jurnal Pendidikan Dan Kebudayaan, 9(1), 62-75.

Slavin, R. E. (2009). Psikologi Pendidikan: Teori dan Praktik Edisi 8 Jilid 2. Jakarta: Indeks.

Stiller, K. D., \& Schworm, S. (2019). Game-Based Learning of the Structure and Functioning of Body Cells in a Foreign Language: Effects on Motivation, Cognitive Load, and Performance. Frontiers in Education, 4(March), 1-19. https://doi.org/10.3389/feduc.2019.00018

Syarif, I. (2012). The Influence of Blended Learning Model on Motivation and Achievement of Vocational. Jurnal Pendidikan Vokasi, 2, 234-249. 
Pengaruh Game-Based Learning Terhadap Motivasi dan Prestasi Belajar

(Komang Redy Winatha, I Made Dedy Setiawan)

Vusić, D., Bernik, A., \& Geček, R. (2018). Instructional Design in Game Based Learning and Applications Used in Educational Systems. Technical Journal, 1(2), 11-17.

Wahyuni, A. (2011). Mengasah Interpersonal Skills Mahasiswa Calon Pendidik. Pedagogia, 1(1), 110.

Yien, J. M., Hung, C. M., Hwang, G. J., \& Lin, Y. C. (2011). A game-based learning approach to improving students' learning achievements in a nutrition course. Turkish Online Journal of Educational Technology, 10(2), 1-10. https://doi.org/10.1055/s-2003-812397 